\title{
Factors that influence transaction costs in development offsets: Who bears what and why?
}

\author{
Anthea Coggan ${ }^{\text {a,b,* }}$, Edwin Buitelaar ${ }^{\text {c,e, } 1}$, Stuart Whitten ${ }^{\text {d,2 }}$, Jeff Bennett ${ }^{\text {b, } 3}$ \\ a CSIRO Ecosystem Sciences, EcoSciences Precinct, 41 Boggo Rd, Dutton Park, Queensland, Australia \\ ${ }^{b}$ Crawford School of Public Policy, Australian National University, Canberra, Australia \\ c PBL Netherlands Environmental Assessment Agency, Oranjebuitensingel 6, 2511 VE Den Haag, The Netherlands \\ d CSIRO Ecosystem Sciences, Gungahlin Homestead, Bellenden St, Gungahlin, Canberra, Australia \\ e Netherlands and Amsterdam School of Real Estate, University of Amsterdam, Netherlands
}

\section{A R T I C L E I N F O}

\section{Article history}

Received 31 May 2012

Received in revised form 29 November 2012

Accepted 5 December 2012

Available online 19 January 2013

\section{Keywords:}

Transaction costs

Influencing factors

Environmental policy

Development offsets

\begin{abstract}
A B S T R A C T
Environmental policy instruments generate transaction costs to public and private parties. There is a growing literature reporting on the size of transaction costs produced by environmental policy instruments. This paper extends that literature through an analysis of the factors that influence transaction costs in environmental policy and how this influence occurs. The theory based factors that influence transaction costs are categorised as: 1) transaction characteristics; 2) transactor characteristics; 3) nature of the institutional environment; and 4) nature of the institutional arrangements. We examined how these factors influenced transaction costs through the analysis of two Australian-based development offset schemes with different policy designs. We found evidence of all four theory-based categories of influence in the policy case studies. The degree of influence and how each factor influenced transaction costs varies across the two policies and between parties. Policy design as a component of the institutional environment had a particularly large bearing on transaction costs of offset buyers and the policy administrator. An important contribution to transaction cost theory assumes the institutional environment as given.
\end{abstract}

(c) 2013 Elsevier B.V. All rights reserved.

\section{Introduction}

When environmental goods and services such as clean air, clean water or habitat for endangered fauna are not provided to the socially optimal level through markets, government intervention may be justified (Vatn, 1998; Wills, 1997). Governments are becoming increasingly interested in policies which assign property rights to environmental goods and services and facilitate trade in rights to protect or deliver these desired environmental goods and services (for example, the Australian Government has a history of implementing market-based instruments www. marketbasedinstruments.gov.au). The caveat on government intervention is that the benefits of introducing the intervention relative to the status quo must be greater than the costs. Calculations of benefits and costs

\footnotetext{
Abbreviations: BRABA, Building Resilient Australian Biodiversity Assets; CSIRO, Commonwealth Scientific Industrial Research Organisation; EPBC, Environmental Protection Biodiversity Conservation (Act); VMA, Vegetation Management Act.

* Corresponding author at: CSIRO Ecosystem Sciences, EcoSciences Precinct, 41 Boggo

Rd, Dutton Park, Queensland, Australia. Tel.: +61 73833 5735; fax: +61 738335505.

E-mail addresses: anthea.coggan@csiro.au (A. Coggan), edwin.buitelaar@pbl.nl

(E. Buitelaar), stuart.whitten@csiro.au (S. Whitten), jeff.bennett@anu.edu.au

(J. Bennett).

1 Tel.: + 31703288722 .

2 Tel.: + 61262421683 .

3 Tel.: +61261250154
}

should extend beyond changes to producer and consumer surpluses to include transaction costs: the costs to define, establish, maintain and exchange property rights (McCann et al., 2005) as well as the costs to change organisations and institutions and define the problems that these institutions and organisations are intended to solve (Marshall, 2013-this issue; McCann, 2013-this issue).

There is a growing literature reporting the extent of transaction costs incurred by administrators of environmental policy and private parties who engage with the environmental policy as well as analyses as to why transaction costs occurred (Falconer, 2000, 2002; Falconer et al., 2001; Garrick et al., 2013-this issue; Kuperan et al., 2008; McCann and Easter, 2000; Mettepenningen et al., 2009; Ofei-Mensah and Bennett, 2013-this issue; Rorstad et al., 2007; Vatn et al., 2002). In this paper we make four contributions to that literature. First, we extend the literature by exploring what factors influence transaction costs to public and private parties in an environmental policy and how this influence occurs. ${ }^{4}$ This discussion is aimed at policy makers. Second, we

\footnotetext{
${ }^{4}$ Ofei-Mensah and Bennett (2013-this issue) highlight the need for this type of analysis in their paper.
} 
highlight the importance of policy design, a component of the institutional environment, on transaction costs. A further theoretical contribution is the introduction of input specificity. Finally, we focus on these issues as they pertain to a specific environmental policy which seeks to generate terrestrial conservation through the allocation of property rights and the facilitation of trade. This type of policy is in contrast to government payment for voluntary actions, such as agri-environmental schemes, which have been the primary focus of the literature to date (Ducos and Dupraz, 2006; Ducos et al., 2009; Mettepenningen et al., 2009, 2011; Nilsson, 2009; Rorstad et al., 2007).

The environmental policy analysed in this paper is a development offset. Development offsets (referred to as offsets) are a form of environmental policy that allows development to impact on the environment provided that impact is mitigated on the development site, on another site (third-party offset) or in non-physical ways such that there is no net loss in the supply of environmental goods and services (Gibbons and Lindenmayer, 2007; Moilanen et al., 2009; Norton, 2009; ten Kate et al., 2004). There is much debate within the ecological literature surrounding what can be used as an offset (Gibbons and Lindenmayer, 2007; Maron et al., 2012). For example, offsetting activities may include planting trees or protecting existing vegetation in perpetuity. There are often limits to what can be offset, however. For instance, development approval and permitting provisions may require damage to be avoided or minimised on-site before an offset is allowed. It is also possible that some on-site impact mitigation may be required before an offset is allowed. By requiring mitigation but facilitating flexibility, in theory, offsets allow no-net-impact from a development to be achieved at a least cost. The concept of third-party offsets, the offset scheme type concentrated on in this paper is illustrated in Fig. 1.

A third-party offset transaction involves developers as the offset buyers, landholders as the offset sellers and the policy administrator as the regulator who requires the purchase of the offset as part of the development approval, approves the offset transaction and often holds the conservation contract with the offset seller. Many offset exchanges also include additional parties who assist in the exchange through information provision or brokering services. These parties are referred to as intermediaries (Coggan et al., 2013).

The paper is structured as follows. The analytical framework used to understand the factors that influence environmental policy transaction costs is discussed in Section 2. The methodology for empirically examining if and how these factors influence transaction costs for an environmental policy is set out in Section 3. Results and analysis are reported in Section 4. Conclusions are drawn in Section 5.

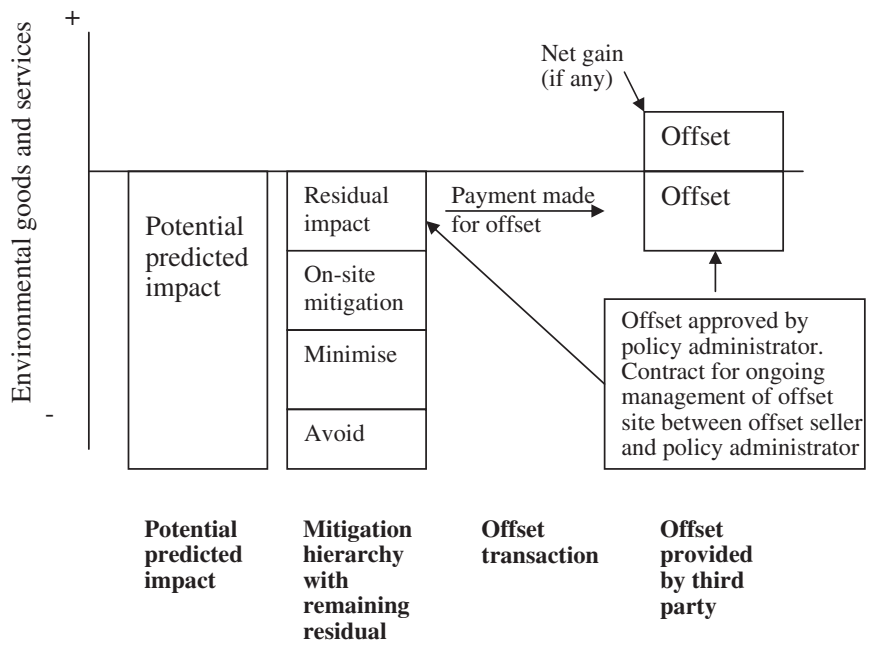

Fig. 1. Offsets within the mitigation hierarchy. Source: Adapted from Crowe and ten Kate (2010).

\section{Analytical Framework}

\subsection{Transaction Costs}

There is extensive literature defining transaction costs (Allen, 1991; Barzel, 1985; Cheung, 1969; Coase, 1960; Dahlman, 1979; North, 1990b; Stiglitz, 1986; Vatn, 1998; Wang, 2007; Williamson, 1973, 1981, 1998). Reviewing this extensive literature for the application to environmental policy, McCann et al. (2005) define transaction costs as the cost of resources used to create and use a policy through defining, establishing, maintaining and transferring property rights. This has been a widely used definition in the literature exploring transaction costs in environmental policy. This definition is updated in this to also include the costs to change organisations and institutions and define the problems that these institutions and organisations are intended to solve (Marshall, 2013-this issue; McCann, 2013-this issue). In this paper the focus is on the transaction costs of policy use only. For an environmental policy, transaction costs are experienced by the administrator and private parties are affected by the policy. Transaction costs are incurred due to expenditure on supplies, travel and time/labour associated with the activities of: information collection and analysis; policy development, enactment and implementation; contracting; and compliance and enforcement (Table 1) (Coggan et al., 2010; McCann et al., 2005).

\subsection{Factors that Influence Transaction Costs}

Understanding the factors that influence transaction costs to all parties in an environmental policy derives from a contract cost analysis within organisational economics (Williamson, 1975, 1981, $1985,1996,1998,1999)$ and its critics that pay attention to a broader range of sources of costs (Challen, 2000; McCann et al., 2005; North, 1990a; Vatn and Bromley, 1994). Empirical analyses of environmental policy have generated a further detailed understanding of transaction costs (Buitelaar, 2007; Falconer, 2000, 2002; Falconer and Saunders, 2002; Falconer and Whitby, 1999; Falconer et al., 2001; McCann and Easter, 1999; Mettepenningen and Van Huylenbroeck, 2009; Nilsson, 2009; Rorstad et al., 2007). A number of studies also explicitly discuss factors that influence transaction costs (Ducos and Dupraz, 2006; Ducos et al., 2009; Falconer and Saunders, 2002; Falconer et al., 2001; McCann, 2013-this issue; Mettepenningen and Van Huylenbroeck, 2009; Mettepenningen et al., 2011; Nilsson,

Table 1

Transaction costs in offset policy creation and use. Source: Adapted from Coggan et al. (2010) and McCann et al. (2005).

\begin{tabular}{|c|c|c|}
\hline \multirow{2}{*}{$\begin{array}{l}\text { Type of } \\
\text { transaction cost }\end{array}$} & \multicolumn{2}{|c|}{ Activities that generate transaction cost to } \\
\hline & Public party & Private party \\
\hline $\begin{array}{c}\text { Information } \\
\text { collection }\end{array}$ & $\begin{array}{l}\text { Problem analysis, policy } \\
\text { design }\end{array}$ & Learning about the policy \\
\hline $\begin{array}{l}\text { Policy } \\
\text { enactment }\end{array}$ & $\begin{array}{l}\text { Policy briefing, legislation } \\
\text { change }\end{array}$ & Lobbying for or against the policy \\
\hline Implementation & $\begin{array}{l}\text { Hiring and training staff, } \\
\text { equipment purchase }\end{array}$ & Equipment purchase \\
\hline Contracting & $\begin{array}{l}\text { Allocating permits, assessing } \\
\text { and approving transactions }\end{array}$ & $\begin{array}{l}\text { Finding trading partner, } \\
\text { negotiating and finalising } \\
\text { offset requirements, negotiating } \\
\text { management plans }\end{array}$ \\
\hline $\begin{array}{l}\text { Support and } \\
\text { administration }\end{array}$ & $\begin{array}{l}\text { Assessing applications, } \\
\text { auditing process }\end{array}$ & $\begin{array}{l}\text { Preparing applications, } \\
\text { record keeping }\end{array}$ \\
\hline $\begin{array}{l}\text { Compliance } \\
\text { monitoring }\end{array}$ & $\begin{array}{l}\text { Auditing compliance, } \\
\text { reporting } \\
\text { effectiveness }\end{array}$ & $\begin{array}{l}\text { Conducting and reporting on } \\
\text { monitoring }\end{array}$ \\
\hline $\begin{array}{l}\text { Detection and } \\
\text { enforcement }\end{array}$ & $\begin{array}{l}\text { Time and cost of } \\
\text { litigation }\end{array}$ & Defence of property rights/actions \\
\hline
\end{tabular}


2009; Rorstad et al., 2007). We synthesise this literature, concluding that transaction costs in environmental policies are influenced by:

1) The characteristics of the transaction: degree of asset specificity, ${ }^{5}$ institutional and biophysical uncertainty surrounding transactions and transaction frequency (Williamson, 1985);

2) The characteristics of the transactors: bounded rationality and broad past experience (Challen, 2000; Ducos and Dupraz, 2006; Libecap, 1989; Mettepenningen and Van Huylenbroeck, 2009), opportunism (Williamson, 1985), trust and confidence in information shared between parties (Ducos and Dupraz, 2006; Ducos et al., 2009; Mettepenningen and Van Huylenbroeck, 2009; Morrison et al., 2008) and social connectedness (Morrison et al., 2008);

3) The nature of the institutional environment: the formal and informal legal, social and political rules that determine the context within which economic activity takes place (Buitelaar, 2007; Easter and McCann, 2010; North, 1991; Vatn, 2010; Williamson, 2000); and

4) The nature of the institutional arrangements: the way exchange of goods and services is coordinated (Challen, 2000; Easter and McCann, 2010; McCann and Easter, 1999, 2000; North, 1990a; Vatn and Bromley, 1994; Williamson, 1998, 2000).

The purpose of this paper is to examine how these theory-based factors influence the scale of transaction costs of all parties in two Australian offset schemes. The hierarchy of influence; direction and variance of influence between parties and across the two case study schemes; and the effect of the interaction between influences are also investigated. Each of the factors that influence transaction costs are discussed in the remainder of this section.

\subsubsection{Characteristics of the Transaction}

Williamson $(1981,1996,1998)$ describes the characteristics of a transaction in terms of asset specificity, frequency, and uncertainty. Asset specificity is a "specialised investment that cannot be redeployed to alternative uses or by alternative users without a loss in productive value" (Williamson, 1996:377). Asset specificity results in non-standard contracting and idiosyncratic exchanges (Williamson, 1981). Asset specificity can be related to the site of production, physical and dedicated assets, human capacity (Williamson, 1981), brand name (Williamson, 1985), time of production (Malone et al., 1987; Masten et al., 1991) and procedural specificity (Zaheer and Venkatraman, 1993). Each form of asset specificity is defined in Table 2 .

Asset specificity is likely to exist in a number of forms for an environmental good such as an offset transaction. ${ }^{6}$ Due to the location and nature of the development impact, a buyer may have very specific requirements (imposed by the administrator) for the location or configuration of a supply site (landscape configuration with feed, breed and roost habitat for example), with alternative sites less valuable as an offset (site specificity). Buyers and sellers may invest in physical capital (electronic mapping equipment, etc.) (dedicated assets) or management inputs (input specificity) to the supply site that cannot be redeployed for another transaction. Asset specificity may also arise for the buyer, seller and administrator if the investment in knowledge for an offset transaction is not re-deployable for another offset or broader transaction (knowledge specificity).

Uncertainty also affects transaction costs. Following Williamson (1985), uncertainty is distilled to three types. The first is uncertainty surrounding what a party may be contracted to do (institutional

\footnotetext{
${ }^{5}$ We note that Ducos and Dupraz (2007) discuss asset specificity as an endogenous variable to decision making surrounding participation in voluntary agri-environmental schemes rather than a driver of transaction costs per se. They note that farmers will offer up asset specific investments if there are other factors that drive down transaction costs (trust, bounded rationality and utility and technology similarity). We don't dispute this relationship. However, we consider asset specificity to be an exogenous driver of transaction costs in this study because participation is compulsory.

${ }^{6}$ Garrick et al. (2013-this issue) also highlight asset specificity as a factor that adds to the complexity and hence transaction costs of water transactions.
}

Table 2

Definitions of types of asset specificity.

Sources: Coggan et al. (2010); de Vita et al. (2011); Williamson (1985, 1986, 1996, 1998).

\begin{tabular}{|c|c|}
\hline Asset specificity & Definition \\
\hline Site specificity & $\begin{array}{l}\text { Where a buyer and supplier are involved in an } \\
\text { exchange relationship with one another due to the } \\
\text { importance of location (proximity or characteristics). } \\
\text { Once in place the } \\
\text { assets are immobile and costly to relocate. }\end{array}$ \\
\hline $\begin{array}{l}\text { Physical asset } \\
\text { specificity }\end{array}$ & $\begin{array}{l}\text { Investments in physical assets that are tailored for a } \\
\text { specific transaction and have few alternative uses } \\
\text { owing to their specific design characteristics (e.g., dyes } \\
\text { developed to be of a certain colour or characteristic for } \\
\text { a cloth type). Referred to in this research as specialised } \\
\text { assets }\end{array}$ \\
\hline Dedicated assets & $\begin{array}{l}\text { Assets of general purpose (e.g., a tractor) which } \\
\text { have been made for a particular transaction } \\
\text { (referred to in this research as dedicated assets) }\end{array}$ \\
\hline $\begin{array}{l}\text { Human capacity } \\
\text { (knowledge specificity) }\end{array}$ & $\begin{array}{l}\text { Degree to which skills, knowledge and experience } \\
\text { of staff are specific to a transaction }\end{array}$ \\
\hline Input specificity & $\begin{array}{l}\text { When inputs (such as land management) are specific } \\
\text { for a particular transaction and are not easily } \\
\text { transferable to other transactions (Coggan et al., 2010) }\end{array}$ \\
\hline Brand name & $\begin{array}{l}\text { Reputation investment - e.g. outsourcing of } \\
\text { restaurants in a hotel to disconnect restaurant from } \\
\text { hotel and protect reputation }\end{array}$ \\
\hline Time & $\begin{array}{l}\text { When the value of an asset is dependent on when } \\
\text { the asset reaches the user }\end{array}$ \\
\hline Procedural & $\begin{array}{l}\text { Particular procedures and routines tailored to a } \\
\text { particular transaction }\end{array}$ \\
\hline
\end{tabular}

uncertainty). For an offset this includes uncertainty about when an offset is appropriate and what can be used as an offset, etc. The institutional environment, and policy design as a component of this, directly affect institutional uncertainty (Buitelaar, 2007; Easter and McCann, 2010; Williamson, 2000). Accordingly, institutional uncertainty is discussed under the heading of policy design in this analysis. The second is uncertainty about the future state of nature as offset outcomes are affected by an uncertain natural environment. This is referred to as biophysical uncertainty. The third type of uncertainty surrounds the behaviour of the contracted parties regarding their obligations and affects the transaction costs of monitoring and enforcement (also included in the discussion of policy design).

The final transaction characteristic that influences transaction costs is the frequency of the offset transactions. Theory suggests that frequent transactions reduce transaction costs due to the ability to re-deploy knowledge and capitalise on standardised processes and contracts (Rorstad et al., 2007; Williamson, 1985).

\subsubsection{Characteristics of the Transactors}

Williamson (1996) suggests that transaction characteristics such as asset specificity would not have a large bearing on transaction costs if transactors had boundless capacity to collect and process information and were always honest in their interactions (i.e., not opportunistic).

Bounded rationality acknowledges that people are rational but with limits in their ability to foresee all contingencies (Simon, 1957). This means that decisions are bounded by the information available to decision makers, the cost of new information, the cognitive limits of the decision makers and the time they have to make a decision. Past experience that improves transactor knowledge can improve decision making ability and influence transaction costs (Challen, 2000; Ducos et al., 2009; Libecap, 1989). Therefore we assess whether broad past experience influences transaction costs of offset buyers, sellers and the administrator. ${ }^{7}$

\footnotetext{
${ }^{7}$ In this analysis we refer to knowledge-based asset specificity (a transaction characteristic) as the ability to transfer specific knowledge about offset transactions across offset transactions. Past experience (a transactor characteristic) relates to broader experiences (not just offset experience) that can be utilised in offset transactions. The ability to use knowledge gained from broader past experiences does depend on the other elements of asset specificity (e.g., site specificity) as our results show.
} 
Opportunism results when transactors are strategically self-interested (secretive, deceptive or guileful) such that they provide false or incomplete information in an effort to redirect profits from vulnerable partners (Carson et al., 2006; Falconer, 2002; Williamson, 1981). Opportunism generates transaction costs through the time and effort invested to develop complete contracts or increased monitoring to manage the risks to transactors from opportunistic behaviours. Ducos and Dupraz (2006), Ducos et al. (2009), Mettepenningen and Van Huylenbroeck (2009) and Morrison et al. (2008) highlight that trust and confidence in the information provided by contracting parties will reduce transaction costs associated with opportunism. Trust and confidence in information is assessed as a separate transactor characteristic influencing transaction costs.

Common preferences about the purpose and operation of a policy and social connectedness through membership of a community of practice are also considered to influence transaction costs (Ducos et al., 2009; Mettepenningen and Van Huylenbroeck, 2009; Morrison, 2009; Morrison et al., 2008).

\subsubsection{Institutional Environment and Arrangements - Policy Design}

The institutional environment is the formal and informal legal, social and political rules that determine the context within which economic activity takes place (Buitelaar, 2007; Easter and McCann, 2010; McCann, 2013-this issue; North, 1991; Vatn, 2010; Williamson, 2000). Institutional arrangements are the governance structures by which the exchange of property rights are organised and contracted for (Buitelaar, 2004; Williamson, 1996). Property right exchange may be via competitive, anonymous and price based markets; mandated exchange (regulation) or exchange based on relationships and negotiation (Buitelaar, 2007; Granovetter, 1973; Williamson, 1985, 1996, 1998).

Williamson's (1985) discriminating alignment application of transaction cost theory focuses on choosing the institutional arrangement that minimises transaction costs for a given outcome. Williamson (2000) refers to over 500 published applications of this approach. By focussing on the institutional arrangements only, however, applications of discriminating alignment treat the institutional environment as given and do not investigate its effect on the institutional arrangements available, transactors, transactions and, ultimately, transaction costs (Buitelaar, 2007; North, 1990a). ${ }^{8}$

In this analysis we assess the impact of policy design, as a component of the institutional environment, on transaction costs. Policy design includes the rules surrounding when an offset can be used, what the offset should be, who can trade, etc. Further, we recognise that policy design also impacts on transaction costs through directing how exchange takes place. For example, the design of the offset scheme may influence whether offset transactions are conducted through relational rather than hierarchical or market-based exchange. By assessing policy design we provide a step toward understanding the impact of the institutional environment and arrangements on transaction costs as well as understanding the influence of the institutional environment in the selection of the institutional arrangements in the discriminating alignment framework (McCann (2013-this issue) also discuss the impact of policy design on transaction costs).

\section{Methodological and Ideological Options}

To be able to identify if and how the theory-based factors influenced transaction costs, a case study methodology was utilised (Yin, 2009). Two development offset schemes with very different institutional setups were selected to allow the investigation of the transaction cost influence of the institutional environment. The first was offsets under the Environment Protection and Biodiversity Conservation (EPBC) Act, 1999

\footnotetext{
${ }^{8}$ We note the further issue of applying discriminating alignment if benefits of different approaches are heterogeneous. This is not discussed further in this paper.
}

(Australian Government, 1999) (referred to as EPBC offsets) which was characterised by few trades and an absence of standardised rules and requirements surrounding offset exchange. The second was offsets under the Vegetation Management Act (VMA) 1999 (Queensland Government, 1999) (referred to as VMA offsets) which was operated with standardised rules and requirements for frequent offset transactions.

Qualitative data were collected from key informants from both case study schemes using semi-structured interviews. Interviews were conducted in late 2009 for the EPBC offset case study and mid 2011 for the VMA offset case study. Informants included offset buyers (developers), sellers (landholders) and key personnel from the policy administrator. Given the large number of offset transactions that occur with intermediary assistance, representatives from intermediaries were also interviewed (Table 3). Interviews included questions about the informants offset transaction (determining offset requirements, finding offset suppliers, determining appropriate management actions, negotiating the offset price, finalising contracts, etc.) as well as questions gauged to understand the characteristics of the transactors (past experience with offsets and other environmental programmes, conservation preferences, etc.). A description of the case study offset schemes follows.

\subsection{Offsets under the Environment Protection and Biodiversity Conservation (EPBC) Act 1999}

The EPBC Act 1999 is the Australian Government's key piece of legislation for the protection of matters of national environmental significance (NES). Any action or activity that may have an impact on a species or ecological community listed as NES triggers the EPBC Act 1999 and therefore has to be 'referred' to the federal government. Once referred, the federal government reviews the application and, if accepted and deemed necessary, places conditions on the development approval, which may include offsets, and then 'consults' on these conditions with the developer. Offset determination proceeds on a case by case basis. At the time of interview, there were very few well defined and consistent rules guiding EPBC offsets. EPBC offsets can include indirect activities such as research, direct non physical activities such as financial contribution towards or actual road management, or direct physical offsets such as conservation. For this research we concentrated on direct physical offsets.

EPBC offsets have been extensively required in Queensland's Mission Beach area due to a large development interest and the potential for development to impact on the population of the Southern Cassowary (Casuarius casuarius johnsonii), a critically endangered large flightless bird (Latch, 2007; Moore, 2007). At the end of 2011 there were 25 developments in the Mission Beach area that had been referred for assessment under the EPBC Act 1999. Six development applications required offsets.

\subsection{Offsets under the Queensland Government Vegetation Management Act (VMA) 1999}

Clearing of remnant vegetation on freehold land in Queensland is regulated by the Vegetation Management Act (VMA) 1999 (Queensland Government, 1999). Clearing applications are assessed by using assessment codes which articulate performance requirements and acceptable solutions (Queensland Government, 2009a). Land-based VMA offsets can be proposed as an alternative solution to meet the performance requirements after it is demonstrated that impacts have been avoided and minimised as much as possible (Queensland Government, 2009b). The final agreement on the offset requirement and offset site is determined after a process of negotiation between the administrator and developer within the codified rules of the Queensland Government offset policy. The administrator also negotiates with the offset provider regarding management of the offset site and its protection over time. The offset buyer and seller negotiate the price. At the end of 2011 there had been between 60 and 80 clearing applications in Queensland that required an offset. 
Table 3

Key informant type and numbers interviewed.

\begin{tabular}{|c|c|c|c|c|c|}
\hline \multicolumn{3}{|l|}{ EPBC offsets } & \multicolumn{3}{|l|}{ VMA offsets } \\
\hline Key informant type & $\begin{array}{l}\text { Key informants } \\
\text { interviewed }\end{array}$ & Notes & $\begin{array}{l}\text { Key informant } \\
\text { type }\end{array}$ & $\begin{array}{l}\text { Key informants } \\
\text { interviewed }\end{array}$ & Notes \\
\hline Offset buyers (developers) & 5 & $\begin{array}{l}6 \text { developers had offsets as a part of their } \\
\text { approval conditions }\end{array}$ & $\begin{array}{l}\text { Offset buyers } \\
\text { (developers) }\end{array}$ & 5 & Representing 16 developments \\
\hline Offset seller (landholder) & 2 & $\begin{array}{l}\text { One as a first party supplier }{ }^{\mathrm{a}} \text { and one as a } \\
\text { third party supplier }{ }^{\mathrm{b}} \text {. The third party } \\
\text { supplier did not complete the sale }\end{array}$ & Offset sellers (landholders) & 5 & \\
\hline $\begin{array}{l}\text { Administrator: EPBC Act } \\
\text { approvals branch }\end{array}$ & 5 & & $\begin{array}{l}\text { Administrator } \\
\text { (on-ground regional) }\end{array}$ & 5 & $\begin{array}{l}\text { Representing all VMA offsets } \\
\text { in their region }\end{array}$ \\
\hline $\begin{array}{l}\text { Administrator: EPBC Act } \\
\text { monitoring and audit branch }\end{array}$ & 2 & & $\begin{array}{l}\text { Administrator } \\
\text { (strategic head office) }\end{array}$ & 3 & $\begin{array}{l}\text { Representing the } 60-80 \\
\text { developments with offset } \\
\text { requirements }\end{array}$ \\
\hline Intermediaries & 4 & $\begin{array}{l}\text { Involved as information provider, } \\
\text { broker and clearing house }\end{array}$ & Intermediaries & 5 & $\begin{array}{l}\text { Representing the } 60-80 \\
\text { developments with offset } \\
\text { requirements }\end{array}$ \\
\hline
\end{tabular}

a Developer with land elsewhere which could be used as a supply site.

b Supplier of offset is separate to the developer.

\section{Results and Analysis}

\subsection{Transaction Attributes and Transaction Costs}

\subsubsection{Asset Specificity}

Both offset schemes required that the environmental goods and services provided by the offset site be of equivalent type and of equal or larger quantity than those impacted by development. Accordingly, administrator expectations regarding the ecology, quality, function, location and management of any proposed offset were high. Offset buyers from both schemes noted that environmental equivalency limited the sites that could be used as an offset making offset transactions site specific. This increased transaction costs through affecting information collection and search requirements. The degree that site specificity affected transaction costs was moderated by the policy design, and specifically by the quality and transparency of communications by the administrator about offset site expectations. VMA offset buyers noted that strict but clear ecological equivalency requirements reduced the effect of site specificity on transaction costs. EPBC offset buyers highlighted that poor communication of expectations increased the impact of site specificity on transaction costs through increased information collection and negotiation effort (Table 4).

Buyers of offsets in both schemes did not have to conduct specific management activities on their site or invest in assets, such as mapping data or software that was specific to the offset transaction. That is, offset buyer transactions were not input, physical or dedicated asset specific. This decreased buyer transaction costs due to avoided information collection, search and negotiation costs. Offset buyers in both schemes noted that specific physical investments were avoided through the use of intermediaries (who did invest in dedicated assets such as mapping software and specific assets such as mapping data). At present the infrequency of offset transactions and the specificity of sites make the purchase of intermediary services the least cost approach to offsets (Coggan et al., 2013).

Offset suppliers in both schemes did not need to invest in assets or management activity inputs specific to an offset transaction. Further,

Table 4

Did and how did asset specificity influence transaction costs?

\begin{tabular}{|c|c|c|c|c|c|c|}
\hline & & \multicolumn{2}{|c|}{ EPBC offsets } & \multicolumn{2}{|c|}{ VMA offsets } & \multirow[t]{2}{*}{ Notes } \\
\hline & & Yes $^{\mathrm{a}}$ & $\mathrm{No}^{\mathrm{b}}$ & Yes $^{\mathrm{a}}$ & $\mathrm{No}^{\mathrm{b}}$ & \\
\hline \multirow[t]{3}{*}{ Site specificity } & Buyer & $\uparrow \uparrow \uparrow$ & & $\uparrow \uparrow$ & & Slightly less for VMA due to policy design \\
\hline & Seller & & $\mathrm{X}$ & & $\mathrm{X}$ & \\
\hline & Administrator & $\uparrow \uparrow \uparrow$ & & $\uparrow \uparrow$ & & Slightly less for VMA due to policy design \\
\hline \multirow[t]{3}{*}{ Input specificity } & Buyer & & $\mathrm{X}$ & & $\mathrm{X}$ & \\
\hline & Seller & & $\mathrm{X}$ & & $\mathrm{X}$ & This could have an impact and depends on policy design \\
\hline & Administrator & & $\mathrm{X}$ & & $\mathrm{X}$ & \\
\hline \multirow[t]{3}{*}{ Physical asset specificity } & Buyer & & $\mathrm{X}$ & & $\mathrm{X}$ & Avoided due to intermediaries \\
\hline & Seller & & $\mathrm{X}$ & & $\mathrm{X}$ & Depends on policy design \\
\hline & Administrator & & $\mathrm{X}$ & & $\mathrm{X}$ & \\
\hline \multirow[t]{3}{*}{ Dedicated asset specificity } & Buyer & & $\mathrm{X}$ & & $\mathrm{X}$ & Avoided due to intermediaries \\
\hline & Seller & & $\mathrm{X}$ & & $\mathrm{X}$ & \\
\hline & Administrator & & $\mathrm{X}$ & & $\mathrm{X}$ & \\
\hline \multirow[t]{3}{*}{ Knowledge specificity } & Buyer & $\uparrow \uparrow \uparrow$ & & $\uparrow \uparrow \uparrow$ & & $\begin{array}{l}\text { Ecological knowledge will always be specific but institutional } \\
\text { knowledge specificity could be reduced through better } \\
\text { management of rule changes and use of intermediaries }\end{array}$ \\
\hline & Seller & & $\mathrm{X}$ & & $\mathrm{X}$ & \\
\hline & Administrator & $\uparrow \uparrow \uparrow$ & & $\uparrow \uparrow$ & & $\begin{array}{l}\text { Slightly less for VMA due to more complete rules and repeatable } \\
\text { processes }\end{array}$ \\
\hline
\end{tabular}

\footnotetext{
a Where the transactions had this feature the number of arrows is an interpretation of the strength of this factor as a driver of transaction costs and the direction of influence.

b Where the transaction did not have this feature assume that this had a downward influence on transaction costs. This basis for strength is as follows and applies for Tables 4 to 12 .

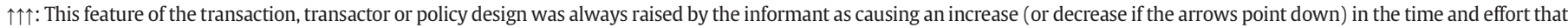
the participant invested in the offset process or was directly referred to as having a large influence on the time and effort that the participant invested in the offset process.

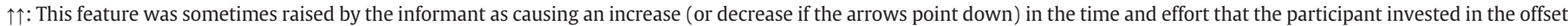
process or was directly referred to as having a moderate influence on the time and effort that the participant invested in the offset process.

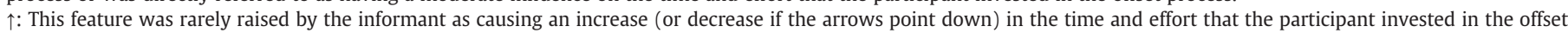
process or was directly referred to as having a small influence on the time and effort that the participant invested in the offset process.
} 
the offset sites were valuable for other offset or conservation transactions. Therefore supplier offset transactions were not site, input, physical or dedicated asset specific. This decreased offset supplier transaction costs. Whilst input and physical asset specificities did not impact on supplier transaction costs, these could occur and are affected by policy design. For example, policy design, primarily through the offset rules, stated that conservation activities did not need to begin until after the offset contract was finalised. A shift in policy design could shift the transaction cost burden related to input specificity.

A key role of the offset administrator in both schemes was to cross check and verify the information provided by offset buyers and sellers to ensure that offset sites would mitigate development impact. The ecological specificities of each offset transaction resulted in administrator information collection activities for verification that were specific to each transaction. Accordingly, the offset transactions of administrators from both schemes were site specific. The influence of site specificity on transaction costs was slightly less for the VMA offset administrator compared to the EPBC offset administrator. This occurred due to policy design and more advanced information collection protocols of the VMA offset administrator. Administrators had also purchased equipment, such as mapping software, in order to conduct buyer and seller site assessments. The majority of these investments could be re-deployed to multiple tasks and therefore were not dedicated assets. The administrators did not need to conduct inputs specific to any offset transaction.

The final type of asset specificity relevant for offsets is knowledge specificity. Offset buyers in both schemes noted high investment in information required for offsets and the limited transferability of this investment between offset transactions (high knowledge specificity). This lack of transferability increased transaction costs due to two factors. First, offsets were required to be as closely related (type, function and location) to the impact on the development site as possible. With no two development impacts or offset sites being the same, new information was required for each negotiation to generate an offset transaction and for each offset transaction. Second, offset buyers from both schemes reported that frequent rule changes, a feature of policy design, resulted in non-transferable institutional knowledge. Many offset buyers in both schemes employed an intermediary to assist with the offset transaction. Due to intermediary experience across many offsets over time, intermediaries reduced the impact of rule changes on buyer transaction costs (buyers did not need to learn the new rules). Intermediaries also reduced costs associated with information collection by providing advice on the offset processes and the type of ecological information that was required. However, because offsets are site specific, ecological data collection was often not transferable between offsets and therefore remained costly for the buyer.

Offset seller transactions under both schemes were not knowledge specific. Sellers in both schemes identified two reasons for this. First, most sellers only engaged in one offset transaction; hence knowledge did not need to be transferred. If the seller did transact another offset, it was usually on the same property enabling low cost knowledge transfer. Second, offsets were supplied by using an existing conservation protection arrangement (Nature Refuge, Voluntary Declaration or Covenant) which are clearly specified and which many sellers were familiar with. Finally, the majority of sellers interviewed in this study used an intermediary. Intermediaries retained institutional knowledge (capitalise on economies of scale) reducing the need for a seller to develop, maintain and transfer knowledge. Low knowledge specificity in offset transactions for sellers decreased seller transaction costs.

Offset transactions tended to be knowledge specific for the administrator in both schemes. Once again this was due to heterogeneous development and offset sites, and the resultant need to collect new information for each offset transaction. The influence that knowledge specificity had on the transaction costs of the administrators varied between the two schemes and was related to how the policy administrator managed the knowledge specificity (policy design). For example, the VMA offset administrator noted that initially, knowledge specificity influenced their transaction costs through continuous policy interpretation for stakeholders and the need to negotiate specific requirements for each offset transaction. However, with frequent VMA offset transactions, the administrator reduced the influence of knowledge specificity on transaction costs in policy implementation through the development of an offset policy with clear rules about offsets and supporting templates for use when applying for, assessing and managing offsets. In this case, transaction frequency interacts with policy design to affect transaction costs. Due to frequent transactions, the VMA offset administrator had also developed knowledge storage and communication systems to limit information collection requirements for each offset transaction. With infrequent and heterogeneous EPBC offsets that occurred in an environment of frequent staff turnover, formal rules, knowledge storage and communication processes had not been developed by the administrator. Accordingly, detailed information collection requirements for each new offset transaction were required, driving up administrator transaction costs for each offset transaction. A summary of the impact of asset specificity on transaction costs is provided in Table 4.

\subsubsection{Biophysical Uncertainty}

Biophysical uncertainty was not a feature of VMA offset buyer transactions because the rules surrounding offsets place the responsibility of offset reporting and risk of offset failure with the offset supplier. This policy design feature had an increasing effect on supplier transaction costs and decreasing effect on buyer transaction costs. At the time of interview, the EPBC offset process occurred as though the responsibility for environmental uncertainty was with the offset sellers. Accordingly, EPBC offset buyers did not see environmental uncertainty as a feature of their offset transactions. The legislation and supporting policies imply that in fact the offset buyer remains responsible for the delivery of the offset under the EPBC Act, 1999, and only contracts with the third party to supply the offset on their behalf. The assignment of risk by the policy administrator highlights the importance of the policy design for the transaction costs of other parties such as offset buyers and sellers.

Environmental uncertainty was a feature of offset transactions for the VMA and EPBC offset administrators. Environmental uncertainty influenced the transaction costs of both administrators through information collection conducted to determine offset supply requirements that take into account environmental risk and the ongoing monitoring and enforcement of offset progress. A summary of the impact of biophysical uncertainty on transaction costs is provided in Table 5.

\subsubsection{Transaction Frequency}

There were no repeat EPBC offset buyers therefore it was not possible to assess the influence of frequency. Many buyers did note that high knowledge specificity would limit the opportunity to capitalise on economics of scale generated from transaction frequency.

Some VMA offset buyers had conducted multiple offset transactions. Once again, these offset buyers noted how specific offset information and knowledge were to each transaction, limiting the ability to capitalise on economies of scale. The discussion with buyers from both

Table 5

Did and how did biophysical uncertainty influence transaction costs?

\begin{tabular}{|c|c|c|c|c|c|}
\hline & \multicolumn{2}{|c|}{$\begin{array}{l}\text { EPBC } \\
\text { offsets }\end{array}$} & \multicolumn{2}{|c|}{$\begin{array}{l}\text { VMA } \\
\text { offsets }\end{array}$} & \multirow[t]{2}{*}{ Notes } \\
\hline & Yes $^{\mathrm{a}}$ & $\mathrm{No}^{\mathrm{b}}$ & Yes $^{\mathrm{a}}$ & $\mathrm{No}^{\mathrm{b}}$ & \\
\hline Buyer & & $\mathrm{X}$ & & $\mathrm{X}$ & Policy rules influenced who bore the risk and \\
\hline Seller & & $\mathrm{X}$ & $\uparrow$ & & cost associated with biophysical uncertainty. \\
\hline Administrator & $\uparrow \uparrow \uparrow$ & & $\uparrow \uparrow$ & & Level affected by complexity of good to offset \\
\hline
\end{tabular}

a Where the transactions had this feature the number of arrows indicates the strength of this factor as a driver of transaction costs and the direction of influence.

b Where the transaction did not have this feature assume that this had a downward influence on transaction costs. 
schemes highlighted the link between asset specificity and frequency when it comes to transaction costs. Frequency will only reduce transaction costs if repeatable rules and processes can be developed which is difficult when transactions are asset specific.

None of the seller informants from either offset schemes had been involved in frequent offset transactions. When asked to comment on the potential influence of frequent transactions, most thought that conducting another offset would be slightly easier due to learning. Sellers also noted that they were dealing with the same land type and similar management activities for each offset transaction. Sellers have lower knowledge specificity than buyers and have a greater opportunity to capitalise on economies of scale.

The influence of frequency on transaction costs varied for the administrators of the offset schemes and was related to policy design. With few and infrequent offsetting occurring for EPBC offsets there had been little action to develop standard offset rules or streamline processes for assessing, negotiating and approving offsets. If the process for establishing and managing offsets remains in its current form and transactions remain highly asset specific, an increase in the frequency of offset transactions could dramatically increase administrator transaction costs.

The VMA offset administrator had developed a number of systems to reduce their transaction costs of managing frequent offset transactions. These systems included a policy to guide developers in proposing offsets, trained regional staff to assist in the finalisation of development applications which included offsets, and standardised metrics and processes for assessing and approving offsets. The VMA offset administrators noted that the specific nature of offsets meant that frequency will continue to positively influence transaction costs. A summary of the impact of frequency on transaction costs is provided in Table 6.

\subsection{Transactor Attributes and Transaction Costs}

\subsubsection{Past Experience}

The discussion about past experience relates to broad past experience rather than past experience in specific offset transactions (which is discussed as knowledge asset specificity). Buyers from both schemes noted that past experience in complex negotiations reduced time and information collection costs associated with offset contracting. VMA offset buyers also noted that past experience working within government agencies developing and managing environmental policy decreased information collection and contracting costs. Past experience in land management also decreased information collection and contracting costs such as the cost to determine the offset offer price. Buyers from both schemes noted that the highly specific nature of the offset transactions limited the ability for past experience to reduce transaction costs.

VMA and EPBC offset sellers noted that past involvement in environmental programmes reduced their information collection and contracting costs due to a familiarity with land management planning. This past experience also made sellers more receptive to the offset concept.

Administrators for both schemes reported past experience in policy development, implementation and administration reducing information collection, communication and negotiation transaction costs.

Table 6

Did and how did transaction frequency influence transaction costs?

\begin{tabular}{llll}
\hline & $\begin{array}{l}\text { EPBC } \\
\text { offsets }\end{array}$ & $\begin{array}{l}\text { VMA } \\
\text { offsets }\end{array}$ & Notes \\
\hline & Yes $^{\mathrm{a}} \quad \mathrm{No}^{\mathrm{b}}$ & $\mathrm{Yes}^{\mathrm{a}} \quad \mathrm{No}^{\mathrm{b}}$ & \\
Buyer & $\uparrow$ & $\uparrow$ & $\begin{array}{l}\text { Impact of frequency depends on } \\
\text { Seller }\end{array}$ \\
Administrator & $\uparrow \uparrow$ & $\downarrow \downarrow$ & transferability of knowledge. Knowledge \\
\hline
\end{tabular}

a Where the transactions had this feature the number of arrows indicates the strength of this factor as a driver of transaction costs and the direction of influence.

b Where the transaction did not have this feature assume that this had a downward influence on transaction costs.
Table 7

Did and how did broad past experience influence transaction costs?

\begin{tabular}{llll}
\hline & $\begin{array}{l}\text { EPBC } \\
\text { offsets }\end{array}$ & $\begin{array}{l}\text { VMA } \\
\text { offsets }\end{array}$ & Notes \\
\hline & Yes $^{\mathrm{a}} \quad \mathrm{No}^{\mathrm{b}}$ & $\mathrm{Yes}^{\mathrm{a}} \quad \mathrm{No}^{\mathrm{b}}$ & \\
Buyer & $\downarrow$ & $\downarrow$ & Transferability of knowledge influenced \\
Seller & $\downarrow$ & $\downarrow$ & the extent that broad past experience \\
Administrator & $\downarrow$ & $\downarrow$ & affected transaction costs \\
\hline
\end{tabular}

a Where the transactions had this feature the number of arrows indicates the strength of this factor as a driver of transaction costs and the direction of influence.

$\mathrm{b}$ Where the transaction did not have this feature assume that this had a downward influence on transaction costs.

VMA administrators highlighted the value of public consultation noting that this reduced information collection costs in policy design and implementation.

On-ground policy officers for VMA offsets noted the downward influence on transaction costs of past experience in conservation management. Knowing what ecological information to collect without input from head office reduced information collection and negotiation transaction costs to all parties. Officers also noted that past experience made it easy to see anomalies in information provided by participants and target site visits. A summary of the impact of past experience on transaction costs is provided in Table 7 .

\subsubsection{Opportunism}

Offset buyers and sellers had the potential to be opportunistic in their transactions. However, because policy design resulted in the administrator verifying and approving all trades, the transaction cost influence of opportunism was managed and borne by the administrator. For both offset schemes, potential opportunism influenced administrator transaction costs through the activities of biophysical information verification prior to offset approval and ongoing enforcement of offset works (Table 8).

\subsubsection{Trust and Confidence in Information and Other Participants}

Confidence in information, processes and other participants influenced the transaction costs of offset buyers and sellers in both schemes. EPBC offset buyers had a general lack of confidence in the information provided by the administrator. This increased the negotiation costs of the offset buyers as they sought to verify information. Confidence in information provided by the administrator tended to be higher for VMA offset buyers due to clear legislation, rules and processes and the involvement of experienced brokers. The fact that a number of these buyers had positive experiences with offsets in the past increased confidence and reduced information collection activities.

Confidence in information also influenced the transaction costs of the administrators of both schemes. Administrators noted that high information confidence reduced desk and site based information collection activities and on-ground monitoring. The VMA offset administrator noted that offset transactions often occurred through a broker/consultant and frequency of transactions has resulted in the VMA administrator learning which brokers/consultants present quality proposals and which require

Table 8

Did and how did opportunism influence transaction costs?

\begin{tabular}{|c|c|c|c|c|c|}
\hline & \multicolumn{2}{|c|}{$\begin{array}{l}\text { EPBC } \\
\text { offsets }\end{array}$} & \multicolumn{2}{|c|}{$\begin{array}{l}\text { VMA } \\
\text { offsets }\end{array}$} & \multirow[t]{2}{*}{ Notes } \\
\hline & Yes $^{\mathrm{a}}$ & $\mathrm{No}^{\mathrm{b}}$ & Yes $^{\mathrm{a}}$ & $\mathrm{No}^{\mathrm{b}}$ & \\
\hline Buyer & & $\mathrm{X}$ & & $\mathrm{X}$ & Opportunism was managed by \\
\hline Seller & & $\mathrm{X}$ & & $\mathrm{X}$ & administrator \\
\hline Administrator & $\uparrow$ & & $\uparrow$ & & \\
\hline
\end{tabular}

a Where the transactions had this feature the number of arrows indicates the strength of this factor as a driver of transaction costs and the direction of influence.

$\mathrm{b}$ Where the transaction did not have this feature assume that this had a downward influence on transaction costs. 
Table 9

Did and how did trust and confidence influence transaction costs?

\begin{tabular}{|c|c|c|c|}
\hline & $\begin{array}{l}\text { EPBC } \\
\text { offsets }\end{array}$ & $\begin{array}{l}\text { VMA } \\
\text { offsets }\end{array}$ & Notes \\
\hline & $\mathrm{Yes}^{\mathrm{a}} \mathrm{No}^{\mathrm{b}}$ & $\mathrm{Yes}^{\mathrm{a}} \mathrm{No}^{\mathrm{b}}$ & \\
\hline Buyer & $\uparrow$ & $\downarrow$ & Direction of influence depended on the \\
\hline Seller & $\downarrow$ & $\downarrow$ & level of confidence in information. \\
\hline Administrator & $\downarrow \downarrow$ & $\downarrow \downarrow$ & $\begin{array}{l}\text { Confidence in information was enhanced by } \\
\text { the number of offsets previously managed. }\end{array}$ \\
\hline
\end{tabular}

a Where the transactions had this feature the number of arrows indicates the strength of this factor as a driver of transaction costs and the direction of influence.

b Where the transaction did not have this feature assume that this had a downward influence on transaction costs.

additional attention. A summary of the impact of trust and confidence on transaction costs is provided in Table 9.

\subsubsection{Common Preferences}

The influence of common preferences on buyer transaction costs varied between the two schemes. Many VMA offset buyers commented that the regulatory nature of a policy removed the influence that common preferences can have on transaction costs. One VMA offset buyer stated that you have to comply so there is no point debating it. EPBC offsets are also regulatory but there was a much greater degree of 'pushing back' against this policy from buyers. A lack of common preferences between buyers and the administrator increased transaction costs to both parties in policy implementation and administration due to ongoing negotiation of offset conditions and continuous interpretation and debate surrounding the policy.

All VMA offset sellers mentioned their enthusiasm for conservation. Agreement with the conservation objectives of the offsets decreased the transaction costs of sellers and the administrator through reduced need for information collection and dissemination and reduced negotiation effort. A summary of the impact of common preferences on transaction costs is provided in Table 10.

\subsubsection{Community of Practice}

EPBC offset buyers, sellers and the administrator had access to a committee of industry, community and concerned citizens focussed on cassowary conservation. Some offset buyers found that interaction with the committee and access to reference documents had a decreasing influence on information collection transaction costs. Other offset buyers and the administrator found that interaction with the committee increased transaction costs due to the time required for this interaction.

Local environmental groups and professional societies functioned as the communities of practice for VMA offset participants. Membership of a community of practice decreased the information collection transaction costs of offset buyers. Buyers noted that the influence on information collection costs of the community of practice is limited due to the asset specific nature of offset transactions. Offset sellers found that being a member of a professional or common interest

Table 10

Did and how did common preferences influence transaction costs?

\begin{tabular}{|c|c|c|c|c|}
\hline & \multicolumn{2}{|c|}{$\begin{array}{l}\text { EPBC } \\
\text { offsets }\end{array}$} & $\begin{array}{l}\text { VMA } \\
\text { offsets }\end{array}$ & \multirow[t]{2}{*}{ Notes } \\
\hline & Yes $^{a}$ & $\mathrm{No}^{\mathrm{b}}$ & $\mathrm{Yes}^{\mathrm{a}} \quad \mathrm{No}^{\mathrm{b}}$ & \\
\hline Buyer & $\uparrow$ & & $\downarrow$ & $\begin{array}{l}\text { Direction depended on agreement or } \\
\text { disagreement with policy. }\end{array}$ \\
\hline Seller & $\downarrow$ & & $\downarrow$ & \\
\hline Administrator & $\uparrow$ & & $\downarrow$ & \\
\hline
\end{tabular}

${ }^{a}$ Where the transactions had this feature the number of arrows indicates the strength of this factor as a driver of transaction costs and the direction of influence.

$\mathrm{b}$ Where the transaction did not have this feature assume that this had a downward influence on transaction costs. organisation reduced the transaction costs of developing land management plans.

A number of VMA administrators were members of environmental or disciplinary communities of practice. Membership decreased transaction costs due to information access and a general feel for current pertinent conservation issues. The influence on transaction costs was limited by the specificity of information required for offsets. A summary of the impact of a community of practice on transaction costs is provided in Table 11.

\subsection{Institutional Environment and Arrangements - Policy Design}

The influence of policy design on transaction costs has been discussed at length throughout the discussion of the other influencing factors. This is because policy design moderates the degree to which many of the other factors influence transaction costs. ${ }^{9}$ In this section we highlight components of policy design that influence offset transaction costs which have not yet been discussed, namely: rules about information and participation inclusion; institutional inconsistency (only relevant for EPBC offsets); and means of exchange (relevant to both case studies).

\subsubsection{Rules and Institutional Inconsistency (EPBC Offsets)}

Buyers of EPBC offsets noted that a lack of clear rules about when new information or participants were allowed into the offset negotiation process increased buyer, seller and administrator time and effort required to negotiate and finalise an offset. The time and effort invested by all parties to negotiate an offset were also increased when administrator decisions on offset requirements conflicted with existing institutions (institutional inconsistency). For example, some offset conditions required a cash contribution to agencies who had strict rules surrounding who they could accept cash from (which ruled out buyers). Other conditions required offset activities that could only be conducted by a government agency (such as road works). In a number of cases the offset conditions required land protection through a specific type of state government conservation covenant which was not available in the region.

While clearer policy rules can reduce the transaction costs of buyers, sellers and the administrator during the administration of the policy, rules are not costless to develop (Vatn, 2001; Williamson, 2000). For example, the VMA offset administrator noted that the science required to develop and administer an offset policy was significant, increasing the information collection costs during policy development. Administrators noted that there were a number of policy development activities that, whilst costly to conduct, reduced the administrator's implementation transaction costs and which continue to manage the level of administration costs. These activities included public consultation, which enabled issues to be resolved before implementation, and aligning the VMA offset rules with an existing whole of government policy on offsets (broader institutional environment). Implementation transaction costs were further eased by using existing staff knowledge and coupling the offset policy with existing clearing legislation and assessment frameworks.

\subsubsection{Means of Exchange}

Whilst offset transactions are referred to as a market-based policy (Jack et al., 2008), the finalisation of an offset exchange occurs through negotiation between parties who voluntarily find each other and form an exchange relationship, rather than through an anonymous exchange coordinated through the market or through a mandated process. Contract coordination is reliant on relationship as well as price. This relational form of exchange had both an increasing and decreasing influence on buyer transaction costs. Exchange through relationships increased EPBC offset buyer transaction costs due to unstructured negotiation effort with many interest groups, exacerbated by a lack of boundaries and rules about inclusion. Relational exchange had a decreasing influence on

\footnotetext{
${ }^{9}$ Pannell et al. (2013-this issue) also highlight the impact of policy design on transaction costs.
} 
Table 11

Did and how did having a community of practice influence transaction costs?

\begin{tabular}{|c|c|c|c|}
\hline & $\begin{array}{l}\text { EPBC } \\
\text { offsets }\end{array}$ & $\begin{array}{l}\text { VMA } \\
\text { offsets }\end{array}$ & Notes \\
\hline & $\mathrm{Yes}^{\mathrm{a}} \mathrm{No}^{\mathrm{b}}$ & $\mathrm{Yes}^{\mathrm{a}} \mathrm{No}^{\mathrm{b}}$ & \\
\hline Buyer & $\uparrow \downarrow$ & $\downarrow$ & $\begin{array}{l}\text { Influence depended on time commitments } \\
\text { and transferability of knowledge. }\end{array}$ \\
\hline Seller & $\downarrow$ & $\downarrow$ & \\
\hline Administrator & $\uparrow \downarrow$ & $\downarrow$ & As for buyer \\
\hline
\end{tabular}

${ }^{a}$ Where the transactions had this feature the number of arrows indicates the strength of this factor as a driver of transaction costs and the direction of influence.

b Where the transaction did not have this feature assume that this had a downward influence on transaction costs.

EPBC and VMA offset buyer transaction costs through reduced information collection costs after information sharing relationships were established with the administrator and the intermediaries. The importance of the relationship with the administrator resulted in buyer transaction costs increasing with administrator staff turnover.

The transaction costs of offset suppliers in both schemes were also influenced by the relational nature of offset exchange. Offset suppliers noted that site visits generated a common understanding of the current and future land management options, reducing contracting costs. Once again the experience of the administrator affected the benefit of relational exchange. Inexperienced administrators who recommended inappropriate land management actions or needed to confirm land management actions with head office increased the information collection requirements and negotiation cost of all parties. Offset sellers also noted the upward influence on transaction costs from the inclusion of many parties in offset negotiations and frequent staff turnover.

Relational offset exchange had an upward influence on the transaction costs of the administrator for both offset schemes. This was due to administrator involvement in every transaction, an inevitable consequence of asset specificity. Transaction frequency and administrator experience have resulted in the development of processes and effort targeting such that relational exchange can occur more efficiently. This was most advanced for VMA offsets. A summary of the impact of relational exchange on transaction costs is provided in Table 12.

\section{Conclusions}

Evidence supporting the presence of all theory based influences of transaction cost was found across the two offset schemes. Two factors had a particularly notable influence on transaction costs - asset specificity and policy design. We also found that a number of interactions between factors were important for transaction costs and the degree to which these factors influenced transaction costs varied across parties.

Table 12

Did and how did relational exchange influence transaction costs?

\begin{tabular}{|c|c|c|c|}
\hline & $\begin{array}{l}\text { EPBC } \\
\text { offsets }\end{array}$ & $\begin{array}{l}\text { VMA } \\
\text { offsets }\end{array}$ & Notes \\
\hline & $\mathrm{Yes}^{\mathrm{a}} \mathrm{No}^{\mathrm{b}}$ & $\mathrm{Yes}^{\mathrm{a}} \mathrm{No}^{\mathrm{b}}$ & \\
\hline Buyer & $\uparrow \downarrow$ & $\uparrow \downarrow$ & $\begin{array}{l}\text { Level and direction of influence depended } \\
\text { on policy design and support for relational } \\
\text { exchange (e.g., management of staff } \\
\text { turnover). }\end{array}$ \\
\hline Seller & $\uparrow \downarrow$ & $\uparrow \downarrow$ & $\begin{array}{l}\text { Level and direction influenced by the } \\
\text { expertise of administrator }\end{array}$ \\
\hline Administrator & $\uparrow$ & $\uparrow$ & $\begin{array}{l}\text { Level and direction influenced by } \\
\text { transferability of knowledge and number } \\
\text { of transactions }\end{array}$ \\
\hline
\end{tabular}

a Where the transactions had this feature the number of arrows indicates the strength of this factor as a driver of transaction costs and the direction of influence.

b Where the transaction did not have this feature assume that this had a downward influence on transaction costs.
The very specific ecological nature and objective of offsets (site specificity) resulted in the non-transferability of knowledge gained from past offset transactions to new offset transactions (knowledge specificity) or more broadly the non-transferability of knowledge gained from past experiences. High asset specificity also made it costly to generate clear and consistent rules relevant for all trades which further influenced transaction costs through uncertainty. Knowledge specificity was particularly influential to the transaction costs of the administrator and offset buyers in both schemes and was a key reason for the prevalence of intermediaries such as brokers in offset transactions.

Analysing two offset schemes demonstrated the direct and indirect influences of policy design on transaction costs. These generate a number of lessons for policy and theory. From a policy perspective, clear rules had a direct bearing on buyer and administrator transaction costs through affecting the quantity, type and frequency that information needed to be collected and distributed amongst transactors. Indirectly, policy design has a moderating effect on other influencing factors. For example policy design moderated if a supplier's transaction costs would be influenced by input specificity and whether the transaction costs associated with environmental uncertainty would be borne by buyers or sellers. Further, through setting boundaries and rules of inclusion the policy design also affected the transaction costs associated with the relational exchange of offsets.

Policy design is not a costless process. This is especially the case when transactions are asset specific (as is the case with offsets). Whilst asset specificity makes rule development difficult, where high frequency is anticipated the development of some, even broad, rules is likely to be worthwhile. If asset specific transactions are anticipated to be infrequent (such as EPBC offsets), decisions need to be made about the benefits and cost to all parties of investment in rules (Pannell et al. (2013-this issue) also highlight the benefits and costs of policy design). If the decision is to not invest in rules, other process based means of supporting transactors could be considered. This may include improved consultation on policy change and improved information handover between policy administrator staff.

From a theoretical perspective, the importance of policy design as a component of the institutional environment, suggests that discriminating alignment studies that ignore the institutional environment may be inaccurate. This is because discriminating alignment assumes that the institutional arrangement for contract exchange (hierarchy, market and relational contracting) is freely and deliberately chosen to economise on transaction costs. Our empirical examination demonstrates that, to some extent the way contract can be exchanged are constrained by the institutional environment (Birner and Wittmer (2004) and Easter and McCann (2010) also make this point).

Finally, this study demonstrates that transaction costs are borne by all parties but the cause of transaction cost is not necessarily homogenous across all parties (for example, in this case, asset specificity was a big driver of transaction costs for buyers and administrators but not sellers). This result highlights the importance of considering the causes and then management of transaction costs to all parties into policy design, assessment and revision.

\section{Acknowledgments}

The authors would like to thank the offset buyers, sellers, policy administrators and intermediaries who generously gave their time to be interviewed as parts of this study. The authors also thank Eeva Primmer, Dustin Garrick, Martijn van Grieken, Marcelo Saguan and three anonymous reviewers for their valuable comments on the previous drafts of this manuscript. Finally, the authors would like to thank the CSIRO Building Resilient Australian Biodiversity Assets (BRABA) research theme and the Australian National University (ANU) for support during data collection and writing. All omissions and errors remain the responsibility of the authors. 


\section{References}

Allen, D. 1991. What are transaction costs? Research in Law and Economics 14, 1-18 Australian Government, 1999. The Environment Protection and Biodiversity Conservation Act. ComLaw, Canberra.

Barzel, Y., 1985. Transaction costs: are they just costs? Journal of Institutional and Theoretical Economics 141, 4-16.

Birner, R., Wittmer, H., 2004. On the 'Efficient boundaries of the state': the contribution of transaction-costs economics to the analysis of decentralization and devolution in natural resource management. Environment and Planning C 22,667-685.

Buitelaar, E., 2004. A transaction-cost analysis of the land development process. Urban Studies 41, 2539-2553.

Buitelaar, E., 2007. The Cost of Land Use Decisions: Applying Transaction Cost Economics to Planning and Development. Blackwell, Oxford.

Carson, S.J., Madhok, A., Wu, T., 2006. Uncertainty, opportunism and governance: the effects of volatility and ambiguity on formal and relational contracting. Academy of Management Journal 49, 1058-1077.

Challen, R., 2000. Institutions, Transaction Costs and Environmental Policy. Institutional Reform for Water Resources. Edward Elgar, Northampton, MA.

Cheung, S.N.S., 1969. Transaction costs, risk aversion and choice of contractual agreements. Journal of Law and Economics 12, 23-42

Coase, R.H., 1960. The problem of social cost. Journal of Law and Economics 3, 1-44.

Coggan, A., Whitten, S.M., Bennett, J., 2010. Influences of transaction costs in environmental policy. Ecological Economics 69, 1777-1784.

Coggan, A., Buitelaar, E., Whitten, S.M., Bennett, J., 2013. Intermediaries in environmental offset markets: actions and incentives. Land Use Policy 32 (1), 145-154.

Crowe, M., ten Kate, K., 2010. Biodiversity Offsets: Policy Options for Government. Forest Trends, Washington D.C.

Dahlman, C.J., 1979. The problem of externality. Journal of Law and Economics 22, 141-162.

de Vita, G., Tekaya, A., Wang, C., 2011. The many faces of asset specificity: a critical review of key theoretical perspectives. International Journal of Management Reviews $13,329-348$.

Ducos, G., Dupraz, P., 2006. Private provision of environmental services and transaction costs: agro-environmental contracts in France. Third World Congress of Environmental and Resource Economists, Kyoto, Japan.

Ducos, G., Dupraz, P., 2007. The Asset Specificity Issue in the Private Provision of Environmental Services: Evidence from Agri-Environmental Contracts. Working paper INRA, Rennes.

Ducos, G., Dupraz, P., Bonnieux, F., 2009. Agri-environment contract adoption under fixed and variable compliance costs. Journal of Environmental Planning and Management $52,669-687$.

Easter, K.W., McCann, L., 2010. Nested institutions and the need to improve internationa water institutions. Water Policy 12, 500-516.

Falconer, K., 2000. Farm-level constraints on agri-environmental scheme participation: a transactional perspective. Journal of Rural Studies 16, 379-394.

Falconer, K., 2002. Developing co-operative approaches to agri-environmental policy: a transactions cost perspective on farmer participation in voluntary schemes. In: Hagedorn, K. (Ed.), Environmental Co-operation and Institutional Change: Theories and Policies for European Agriculture. Edward Elgar Publishing Ltd., Cheltenham, U.K.

Falconer, K., Saunders, C., 2002. Transaction costs for SSSIs and policy design. Land Use Policy 19, 157-166.

Falconer, K., Whitby, M., 1999. Transactions and Administrative Costs in Countryside Stewardship Policies: An Investigation for Eight European Member States. University of Newcastle, School of Agriculture, Food and Rural Development, Newcastle.

Falconer, K., Dupraz, P., Whitby, M., 2001. An investigation of policy administrative costs using panel data for the English environmentally sensitive areas. Journal of Agricultural Economics 52, 83-103.

Garrick, D., Whitten, S., Coggan, A., 2013. Understanding the evolution and performance of water markets and allocation policy: A transaction costs analysis framework. Ecological Economics 88, 195-205 (this issue).

Gibbons, P., Lindenmayer, D.B., 2007. Offsets for land clearing: no net loss or the tail wagging the dog? Ecological Management and Restoration 8, 26-31.

Granovetter, M., 1973. The strength of weak ties. The American Journal of Sociology 78 $1360-1380$

Jack, B.K., Kousky, C., Sims, K.R.E., 2008. Designing payments for ecosystem services: lessons from previous experience with incentive-based mechanisms. Proceedings of the National Academy of Sciences of the United States of America 105, 9465-9470.

Kuperan, K., Abdullah, N.M.R., Pomeroy, R.S., Genio, E.L., Salamanca, A.M., 2008. Measuring transaction costs of fisheries co-management. Coastal Management 36, 225-240.

Latch, P., 2007. National recovery plan for the southern cassowary Casuarius casuarius johnsonii. In: Agency, E.P. (Ed.), Report to the Department of the Environment, Water, Heritage and the Arts, Canberra. Environmental Protection Agency, Brisbane.

Libecap, G., 1989. Contracting for Property Rights. Cambridge University Press, Cambridge

Malone, T.W., Yates, J., Benjamin, R.I., 1987. Electronic markets and electronic hierarchies. Communications of the ACM 30, 484-497.

Maron, M., Hobbs, R., Moilanen, A., Matthews, J.W., Christie, K., Gardner, T., Keith, D. indenmayer, D.B. McAlpine, CA, 2012. Faustian bargains? Restoration realities in the context of biodiversity offset policies. Biological Conservation 155, 141-148.

Marshall, G., 2013. Transaction costs, collective action and adaptation in managing complex social-ecological systems. Ecological Economics 88, 185-194 (this issue).

Masten, S.E., Meehan, J.W., Snyder, E.A., 1991. The costs of organisation. Journal of Law, Economics, and Organization 7, 1-25.

McCann, L., 2013. Transaction costs and environmental policy design. Ecological Economics 88, 253-262 (this issue).

McCann, L., Easter, K.W., 1999. Transaction costs of policies to reduce agricultural phosphorous pollution in the Minnesota River. Land Economics 75, 402-414.
McCann, L., Easter, K.W., 2000. Estimates of public sector transaction costs in NRCS programs. Journal of Agricultural and Applied Economics 32, 555-563.

McCann, L., Colby, B., Easter, K.W., Kasterine, A., Kuperan, K.V., 2005. Transaction cost measurement for evaluating environmental policies. Ecological Economics 52, 527-542.

Mettepenningen, E., Van Huylenbroeck, G., 2009. Factors influencing private transaction costs related to agri-environmental schemes in Europe. In: Bruwer, F., van der Heide, M. (Eds.), Multifunctional Rural Land Management: Economics and Policies. Earthscan, London.

Mettepenningen, E., Verspecht, A., Van Huylenbroeck, G., 2009. Measuring private transaction costs of European agri-environmental schemes. Journal of Environmental Planning and Management 52, 649-667.

Mettepenningen, E., Beckmann, V., Eggers, J., 2011. Public transaction costs of agrienvironmental schemes and their determinants - analysing stakeholders' involvement and perceptions. Ecological Economics 70, 641-650.

Moilanen, A., van Teeffelen, A.J.A., Ben-Haim, Y., Ferrier, S., 2009. How much compensation is enough? A framework for incorporating uncertainty and time discounting when calculating offset ratios for impacted habitat. Restoration Ecology 17, 470-478.

Moore, L.A., 2007. Population ecology of the southern cassowary Casuarius casuarius johnsonii, Mission Beach north Queensland. Journal of Ornithology 148, 357-366.

Morrison, M., 2009. Encouraging the adoption of decision support systems by irrigators. Rural Society $19,17-31$.

Morrison, M., Durante, J., Greig, J., Ward, J., 2008. Encouraging participation in market based instruments and incentive programs. Final Report Prepared for Land and Water Australia.

Nilsson, F.O.L., 2009. Transaction costs and agri-environmental policy measures: are preferences influencing policy implementation? Journal of Environmental Planning and Management 52, 757-775.

North, D., 1990a. Institutions, Institutional Change and Economic Performance. Cambridge University Press, Cambridge.

North, D., 1990b. A transaction cost theory of politics. Journal of Theoretical Politics 2 , 355-367.

North, D., 1991. Institutions. Journal of Economic Perspectives 5, 97-112.

Norton, D.A., 2009. Biodiversity offsets: two New Zealand case studies and an assessment framework. Environmental Management 43, 698-706.

Ofei-Mensah, A., Bennett, J., 2013. Transaction costs of alternative greenhouse gas policies in the Australian transport energy sector. Ecological Economics 88, 214-221 (this issue).

Pannell, D.J., Roberts, A., Park, G., Alexander, J., 2013. Improving environmental decisions: A transaction-costs story. Ecological Economics 88, 244-252 (this issue).

Queensland Government, 1999. Vegetation Management Act.

Queensland Government, 2009a. Landholders Guide to Vegetation Clearing Applications. Queensland Government Department of Environment and Resource Management (DERM).

Queensland Government, 2009b. Policy for Vegetation Management Offsets. Department Environment Resource Management (DERM).

Rorstad, P.K., Vatn, A., Kvakkestad, V., 2007. Why do transaction costs of agricultural policies vary? Agricultural Economics 36 (1), 1-11.

Simon, H., 1957. Administrative Behaviour. MacMillan, New York.

Stiglitz, J., 1986. Economics of the Public Sector, Second edition. W.W. Norton and Co., New York.

ten Kate, K., Bishop, J., Bayon, R., 2004. Biodiversity offsets: views, experiences and the business case, in: IUCN (Ed.), Gland, Switzerland and Cambridge, United Kingdom and Insight Investment, London.

Vatn, A., 1998. Input versus emission taxes: environmental taxes in a mass balance and transaction costs perspective. Land Economics 74, 514-525.

Vatn, A., 2001. Environmental resources, property regimes, and efficiency. Environment and Planning C 19, 665-680.

Vatn, A., 2010. An institutional analysis of payments for environmental services. Ecological Economics 69, 1245-1252.

Vatn, A., Bromley, D.W., 1994. Choices without prices without apologies. Journal of Environmental Economics and Management 26, 129-148.

Vatn, A., Kvakkestad, V., Rorstad, P., 2002. Policies for Multifunctional Agriculture, the Trade Off between Transaction Costs and Precision. Department of Economics and Social Sciences, Agricultural University of Norway, Ås, Norway.

Wang, N., 2007. Measuring transaction costs: diverging approaches, contending practices. Division of Labour and Transaction Costs 2,111-146.

Williamson, O., 1973. Markets and hierarchies: some elementary considerations. American Economic Review 63, 316-325.

Williamson, O., 1975. Markets and Hierarchies: Analysis and AntiTrust Implications. Free Press, New York.

Williamson, O., 1981. The economics of organization: the transaction cost approach. The American Journal of Sociology 87, 548-577.

Williamson, O., 1985. The Economic Institutions of Capitalism: Firms, Markets and Relational Contracting. The Free Press, New York.

Williamson, O., 1986. Economic Organisation. New York University Press, New York.

Williamson, O., 1996. The Mechanisms of Governance. Oxford University Press, New York.

Williamson, O. 1998. Transaction cost economics: how it works: where is it headed. De Economist 146, 23-58.

Williamson, O., 1999. Public and private bureaucracies: a transaction costs economics perspective. Journal of Law, Economics, and Organization 15, 306-342.

Williamson, O., 2000. The new institutional economics: taking stock, looking ahead. Journal of Economic Literature 38, 593-613.

Wills, I., 1997. Economics and the Environment; a Signalling and Incentives Approach. Allen and Unwin, St. Leonards.

Yin, R., 2009. Case Study Research: Design and Methods, 4th ed. Thousand Oaks, California.

Zaheer, A., Venkatraman, N., 1993. From transaction cost to transactional value analysis. Implications for the study of inter-organisational strategies. Journal of Management Studies 30, 131-145. 